\title{
Cryopreservation by encapsulation-dehydration affects the vegetative growth of chrysanthemum but does not disturb its chimeric structure
}

\author{
Dariusz Kulus $^{1}$ (D) Monika Rewers ${ }^{2} \cdot$ Magdalena Serocka $^{1} \cdot$ Anna Mikuła $^{3}$
}

Received: 6 December 2018 / Accepted: 26 April 2019 / Published online: 8 May 2019

(c) The Author(s) 2019

\begin{abstract}
Little is known about the stability of plant chimeras after exposure to liquid nitrogen. The aim of this study was to evaluate the effect of cryopreservation on the cytogenetic and genetic stability, as well as vegetative and generative growth of chrysanthemums that are a solid mutant ('Richmond') or periclinal chimeras ('Lady Orange' and 'Lady Salmon'). The following encapsulation-dehydration protocol of shoot tip cryopreservation was applied: $0.09 \mathrm{M}$ sucrose concentration and $10 \mu \mathrm{M}$ abscisic acid during a two-week preculture, followed by a 4-day osmotic dehydration and 3-hour desiccation. Both, the cryopreservation-recovered and control plants were characterized by the same relative DNA content and chromosome number (ploidy level). By applying RAPD and ISSR markers, 18 and 1 and 0 polymorphic loci within cryopreservation-derived 'Lady Orange' and 'Lady Salmon' and 'Richmond' were detected, respectively. The recovered after cryopreservation and control plants had the same colour, diameter and fresh weight of inflorescences, as well as length of ray florets. Cryopreservation also did not affect the flowering time in chrysanthemum. The biochemical assay did not reveal any alternations in the level of anthocyanins and carotenoids in flowers. It was noted, however, that some of the leaves of the cryopreservation-recovered plants were shorter and/or narrower. They had a reduced chlorophyll content, and their internodes were shorter when compared to the untreated control. The inflorescences of 'Lady Salmon' opened slower, but faded faster. In conclusion, these results illustrate the practicability of a cryopreservation method that completely protects the chimera chrysanthemum identity.
\end{abstract}

\section{Key message}

Cryopreservation via encapsulation-dehydration technique affects the vegetative growth of chrysanthemum during the first cultivation season but does not disturb its chimeric structure.

Keywords Biochemical stability $\cdot$ Chimera $\cdot$ Cytogenetic stability $\cdot$ Genotyping $\cdot$ Molecular markers $\cdot$ Phenotype stability

\section{Introduction}

Communicated by M. Angeles Revilla.

Dariusz Kulus

dkulus@gmail.com

1 Laboratory of Ornamental Plants and Vegetable Crops, Faculty of Agriculture and Biotechnology, UTP University of Science and Technology in Bydgoszcz, Bernardyńska 6, 85-029 Bydgoszcz, Poland

2 Laboratory of Molecular Biology and Cytometry, Faculty of Agriculture and Biotechnology, UTP University of Science and Technology in Bydgoszcz, Kaliskiego 7, 85-796 Bydgoszcz, Poland

3 Polish Academy of Sciences Botanical Garden - Center for Biological Diversity Conservation in Powsin, Prawdziwka 2, 02-973 Warsaw, Poland
Chrysanthemum is a popular floricultural crop, second only to the rose in terms of its market value (Guan et al. 2017). As a result of applying mutation breeding, about $50 \%$ of the available chrysanthemum cultivars are chimeras (Miler and Zalewska 2014). Securing the stability of plant chimeras is very difficult. Such plants easily undergo variation due to the heterogenic structure of their meristem resulting from containing at least two genotypes. This structure can be easily and irreversibly disturbed spontaneously or as a result of strong prolonged stress, e.g. improper propagation or storage conditions, including cryoinjury. Moreover, numerous hotspots; i.e. DNA sequences with high mutation frequencies; were identified within the species genome (Rogozin and Pavlov 2003). Consequently, somaclonal variation is often 
reported under in vitro conditions (Zalewska and Kulus 2014). This variation can be a cause of serious financial loss of producers and, therefore, it is highly undesirable. The susceptibility to variation occurrence is cultivar dependent. Chrysanthemums of pink or purple inflorescences undergo mutations most easily (due to the greatest number of dominant alleles determining the flower colour), while the yellow ones; the least often (Miler and Kulus 2018).

The continuously increasing number of available chrysanthemum cultivars (currently there are over 30,000 available), as well as the expanding consumer demands require proper action in terms of preserving the valuable genetic pool (Kulus 2015). Nowadays, cryopreservation; i.e. storage of biological material at ultra-low temperature of liquid nitrogen; is considered to be the most effective long-term preservation method, not only of chrysanthemum but also other vegetatively-propagated plant species (MartinezMontero and Harding 2015; Li et al. 2019). The technology is inexpensive and safe to implement (Kulus and Zalewska 2014). Preparing the explants for storage in liquid nitrogen, however, is quite complex and may become a source of various perturbations (Bi et al. 2016). Maintenance of both the genetic and phenotype fidelity is an extremely important task determining the cryopreservation effectiveness. However, obtaining $100 \%$ homology with the untreated reference may be very difficult (Zarghami et al. 2008).

Complex information on the stability of plants recovered after cryopreservation are very scarce and ambiguous. Previous papers focused commonly on one or two marker systems, usually molecular and cytogenetic, while biochemical and phenotypical ones were much less frequently applied (Martín and González-Benito 2005; Lee et al. 2011; Martín et al. 2011; Wang et al. 2014; Jeon et al. 2015a, b; Bi et al. 2016). As for ornamental plant species, however, those parameters are essential and ought to be carefully monitored. Especially little is yet known about the stability of chimeras stored in LN (liquid nitrogen), and thus they are far from a routine procedure. Up to date, only one publication focused on the stability of cryopreserved chrysanthemum chimeras (Fukai et al. 1994). The described two-step freezing protocol failed to secure the plants chimeric structure as $70 \%$ of recovered chrysanthemums had altered inflorescence colour. There is also evidence showing alternations on the physiological (Zevallos et al. 2013), biochemical (de Oliveira and Paiva 2017), genetic (Matsumoto 2017), and epigenetic (Chatterjee et al. 2017) levels in various plant species after cryostorage. This variation may not only be cultivar- but also generation-dependent, as observed by Muntean et al. (2015). Consequently, South Korea postponed the introduction of chrysanthemum to the National Agrobiodiversity Center, despite the high survival of cryopreserved explants, until the stability of the recovered plants is confirmed (Teixeira da Silva 2014). Therefore, the exploration of the issue is fully justified and necessary for the collection and long-term storage of biological material, especially in the case of chimeras that are common among ornamental plants.

In the previous research we have focused on the optimisation of the chrysanthemum cryopreservation protocol by encapsulation-dehydration technique (Zalewska and Kulus 2013, 2014; Kulus 2018). Although the efficiency of the protocol described was quite high, it was found that cryopreservation may cause some structural damages to the meristem and affect the morphogenetic response of the explants (Kulus et al. 2018a, b). This may result in changes in the stability of plantlets regenerated from cryopreserved of shoot tips. Therefore, in this work, we studied the effect of cryopreservation on the cytogenetic and genetic stability, as well as vegetative and generative growth of chrysanthemums that are a solid mutant ('Richmond') or periclinal chimeras ('Lady Orange' and 'Lady Salmon'). For this purpose, the cytogenetic (DNA content, chromosome number), molecular (RAPD and ISSR), phenotype (inflorescence and leaf physical parameters, flowering time and length, as well as plant habit) and biochemical assay (pigment content in ray florets and leaves) were performed.

\section{Materials and methods}

\section{Plant material, cryopreservation procedure and acclimatisation}

Chrysanthemum (Chrysanthemum $\times$ grandiflorum /Ramat./ Kitam.) 'Richmond' and obtained via radiomutation 'Lady Orange and 'Lady Salmon' (Zalewska et al. 2010) were the source of plant material. Purple-flowering 'Richmond' is a stable cultivar with regard to flower colour while 'Lady Orange' and 'Lady Salmon' are periclinal chimeras (Zalewska et al. 2007).

Plant material was cultured on the modified MS (Murashige and Skoog 1962) medium supplemented with extra $330 \mathrm{mg} \cdot \mathrm{dm}^{-3}$ calcium chloride, $13.9 \mathrm{mg} \cdot \mathrm{dm}^{-3}$ iron sulphate and $0.09 \mathrm{M}$ sucrose. The medium was solidified with 0.8\% agar (Biocorp, Warsaw, Poland), at $\mathrm{pH} 5.8$ prior autoclaving $\left(121^{\circ} \mathrm{C}, 105 \mathrm{kPa}, 20 \mathrm{~min}\right)$ in $350 \mathrm{~mL}$ glass jars. Cultures were maintained in the growth room at $24{ }^{\circ} \mathrm{C} \pm 2{ }^{\circ} \mathrm{C}$, under 16-h photoperiod conditions and photosynthetic photon flux density of $27.4 \mu \mathrm{mol} \cdot \mathrm{m}^{-2} \cdot \mathrm{s}^{-1}$ provided by standard cool daylight TLD 54/36 W fluorescent tubes with colour temperature of $6200 \mathrm{~K}$ (Koninklijke Philips Electronics N.V., Eindhoven, the Netherlands).

The single-node-produced shoot tips (2.0 $\mathrm{mm}$ in length) with two leaf primordia and two young leaves were subjected to an encapsulation-dehydration cryopreservation procedure. The following protocol was applied: $0.09 \mathrm{M}$ sucrose concentration and $10 \mu \mathrm{M}$ abscisic acid during a two-week 
preculture on the modified MS medium, encapsulation in $3 \%$ calcium alginate, followed by a 4-day osmotic dehydration in an increasing sucrose gradient $(0.25-1.0 \mathrm{M})$ and 3-hour desiccation in a stream of sterile air (to a level of $40 \%$ of the initial explant fresh weight) (Kulus et al. 2018a). After rewarming, the recovered plantlets were cultured on the modified MS medium with $1.16 \mu \mathrm{M}$ kinetin in the same growth room for six months and, then, rooted and successfully acclimatised to ex vitro conditions as previously described (Kulus et al. 2018a).

\section{Cultivation in the glasshouse}

All of the recovered plants, i.e. 32 - 'Richmond', 22 - 'Lady Salmon', 36 - 'Lady Orange' and additional 10 ('Lady Salmon' and 'Richmond') or 15 ('Lady Orange') ex vitro-grown controls (i.e. non-treated and non-exposed to $\mathrm{LN}$ ) from each cultivar, were used in the further analyses, unless otherwise stated.

In February, the acclimatised plants were transferred to plastic pots $(18 \mathrm{~cm}$ in diameter, three clones of each genotype per pot) filled with professional peat substrate for chrysanthemum cultivation (Gramoflor Cultivo). The studied chrysanthemum cultivars were planted in a permanent place on benches. Cultivation was performed under controlled light and temperature conditions according to Jerzy and Borkowska (2004). In order to stimulate the vegetative growth, since February the plants were additionally illuminated in the extension of the natural day; 16-18 $\mathrm{h}$ of light; with sodium lamps with an addition of UV light. After reaching a minimum height of $20-30 \mathrm{~cm}$, to stimulate flowering, the plants were shaded; photoperiod: 10-h light and 14-h dark. Chrysanthemums were grown with a standard method, i.e. one stem with a single inflorescence.

\section{Stability analysis}

\section{Cytogenetic analysis}

Samples for flow cytometry were prepared according to Rewers et al. (2012) with the leaf of an internal standard (Pisum sativum 'Set', 2C $=9.11 \mathrm{pg}$; Śliwińska et al. 2005). For each sample, at least 7,000 nuclei were analysed using a Partec CyFlow SL Green (Partec GmbH, Münster, Germany) flow cytometer. Histograms were analysed using the FloMax 2.82 (Partec GmbH, Münster, Germany) software. The nuclear DNA content was calculated using the linear relationship between the ratio of the $\mathrm{G}_{0} / \mathrm{G}_{1}$ peak positions of $C$. grandiflorum and $P$. sativum on the histogram of fluorescence intensities.

The 2C nuclear DNA contents $[\mathrm{pg}]$ were transformed to megabase [Mbp] pairs of nucleotides using the following conversion: $1 \mathrm{pg}=978 \mathrm{Mbp}$ (Doležel et al. 2003). The analysis was repeated twice during in vitro and ex vitro growth of the plants.

\section{Chromosome number determination}

In order to screen the number of chromosomes, the root tips squash technique was applied (Sánchez-Jiménez et al. 2012). Shoots of cryopreservation-recovered and control plants (five from each cultivar, including the ones which showed polymorphic band pattern) were rooted ex vitro in a glasshouse in an aqueous solution of $11.42 \mu \mathrm{M}$ IAA in natural photoperiod in August. On a sunny day morning (8.45$9.45 \mathrm{AM}$ ) roots, approximately $5 \mathrm{~mm}$-long, were collected and chromosomes were counted with an OLYMPUS BX41 microscope (Tokyo, Japan).

\section{Molecular analysis}

Plantlets grown in vitro were evaluated using the RAPD (randomly amplified polymorphic DNA) and ISSR (inter simple sequence short repeats) analysis. Total genomic DNA was isolated from fresh young leaves with a Genomic Mini AX Plant Kit (A\&A Biotechnology, Gdynia, Poland, www. aabiot.com). DNA concentration and purity was monitored spectrophotometrically (UV-VIS 1610 SCHIMADZU, Kyoto, Japan).

Ten most sensitive primers of arbitrary sequence (five for RAPD and five for ISSR, Genomed, Poland, Table 1) were used for PCR (polymerase chain reaction; $2 \times$ PCR Master Mix Plus kit, A\&A Biotechnology, Gdynia, Poland). Each $25 \mu \mathrm{L}$ reaction volume contained $2 \mathrm{mM} \mathrm{MgCl}{ }_{2}$ in Reaction Buffer; $1 \mathrm{mM}$ nucleoside triphosphate solution mix; $1 \mu \mathrm{M}$ single primer; $0.05 \mathrm{U} \cdot \mu \mathrm{L}^{-1}$ Taq DNA polymerase, $0.8 \mathrm{ng} \cdot \mu \mathrm{L}^{-1}$ template DNA (20 ng), and deionized water to volume. Amplification was performed in a BioRad C1000 Touch thermal cycler with heated cover (Bio-Rad Laboratories, Hercules CA, USA) programmed as follows: 45 cycles of $1 \mathrm{~min}$ at $94{ }^{\circ} \mathrm{C}$ for denaturation, $1 \mathrm{~min}$ at $36 / 53{ }^{\circ} \mathrm{C}$ for annealing (RAPD/ISSR, respectively), and $2 \mathrm{~min}$ at $72{ }^{\circ} \mathrm{C}$ for DNA extension. The last cycle was followed by a final extension step of $4 \mathrm{~min}$ at $72{ }^{\circ} \mathrm{C}$ (Lema-Rumińska et al. 2004). The amplified DNA fragments were separated on $1.8 \%(w / v)$ agarose gel DN- and RNase-free (Blirt), in a TBE buffer at $110 \mathrm{~V}$ for $120 \mathrm{~min}$ (Biometra P25, Jena, Germany), and detected by staining with $18 \mu \mathrm{l}$ ethidium bromine at a concentration $10 \mathrm{mg} \cdot \mathrm{mL}^{-1}$ for $300 \mathrm{~mL}$ of gel. Gel images were recorded using a UV transilluminator GelDoc $\mathrm{XR}+$ Gel Photodocumentation System (Bio-Rad, Hercules CA, USA) with Image Lab 4.1 software. Molecular weights of the fragments were estimated using a 100-5000 bp DNA molecular marker (DNA GeneRuler Express DNA Ladder, Fermentas, MA USA). Each PCR amplification products 
Table 1 Primers used in the molecular (RAPD and ISSR) analysis

\begin{tabular}{llll}
\hline No & Symbol & Primer sequence $5^{\prime} \rightarrow 3^{\prime}$ & Reference \\
\hline RAPD & & & \\
1. & R-A & GGGAATTCGG & Lema-Rumińska et al. (2004) \\
2. & R-B & GACCGCTTGT & \\
3. & R-C & GGACTGGAGT & Shibata et al. (1998) \\
4. & R-D & GCTGCCTCAGG & \\
5. & R-E & TACCCAGGAGCG & Palai and Rout (2011) \\
ISSR & & & \\
1. & I-F & GAGGGTGGAGGATCT & Mukherjee et al. (2013) \\
2. & I-G & CGAGAGAGAGAGAGAGA & \\
3. & I-H & CAGAGAGAGAGAGAGAG & \\
4. & I-I & GACAGACAGACAGACA & \\
5. & I-J & GAGAGAGAGAGAGAGAGAT & \\
\hline
\end{tabular}

separation was repeated at least twice to confirm the reproducibility of the results.

The banding patterns, were recorded as 0-1 binary matrices, where " 1 " indicates the presence and " 0 " the absence of a given fragment. For every primer tested, the total number of bands, monomorphic, polymorphic and specific/unique loci was counted.

\section{Phenotype analysis}

The colour of leaves and ray florets of fully developed inflorescences, i.e. of maximal diameter, were estimated using the RHSCC (Royal Horticultural Society Colour Chart) in the natural light.

The morphometric analyses included: the height of plants, length of internodes [cm], the number, length and width $[\mathrm{cm}]$ of bottom, central and upper leaves, the diameter $[\mathrm{cm}]$ and fresh weight $[\mathrm{g}]$ of inflorescences, length of ray florets $[\mathrm{cm}$ ], and the date and length of blooming [days] since bud colouration, through full blooming, until total fading of inflorescences.

\section{Biochemical analysis of pigment content in leaves and inflorescences}

The relative chlorophyll content was measured with an ADC OSI CCM200 Plus (Opti-Sciences, Szczecin, Poland) chlorophyll content meter. For each individual, three leaves from a central part of the shoot were analysed.

Spectrophotometric analysis of greenhouse-grown plant pigments, extracted from inflorescences of 5 control plants and 15 random chrysanthemums derived from cryopreserved shoot tips (at least $50 \%$ of all available plants), was performed. The ray florets were sampled starting from July to August, over full flowering.

In order to extract carotenoids, the Wettstein method (Wettstein 1957) with $100 \%$ acetone was used, while for anthocyanins - the Harborne method (Harborne 1967) was followed based on methanol containing $1 \% \mathrm{HCl}$.

The spectrophotometric analysis of extracts was performed in the two-beam spectrophotometer (UV-VIS 1601PC SHIMADZU). The results were analysed with spectrophotometer software.

Absorption maxima were defined for pigment-specific wavelengths $\left(\lambda_{\max }\right)$ : for carotenoids at $440 \mathrm{~nm}$ and anthocyanins at $530 \mathrm{~nm}$. The content of anthocyanins and carotenoids per gram of fresh matter of ray florets was calculated with the algebraic method following Harborne (1967) and with the coefficient obtained from the Wettstein equation (Wettstein 1957), respectively.

\section{Statistical analysis}

GenAlex 6.5b5 (Peakall and Smouse 2012) software was used to calculate the number of RAPD and ISSR fragments. Measures of genetic uniformity among recovered individuals were determined using the Jaccard dissimilarity coefficient. Genetic XIStat v.2009.2.01 excel add-in software was used to draw the AHC UPGMA (agglomerative hierarchical clustering via unweighted pair group method with arithmetic mean) dendrograms and to perform the PCoA (principle coordinate) analysis. Population groups were distinguished based on AMOVA (analysis of molecular variance) estimates, with the assumption that cryopreservation-derived and control plants are two separate groups.

As for the morphometric and biochemical analyses, after the appropriate normality transformation, the results (completely randomised design) were statistically analysed with the analysis of variance (ANOVA), and the comparisons of means were made with Newman-Keuls Multiple Comparison Test $(P \leq 0.05)$ using Statistica 12.0 tools (StatSoft, Cracow, Poland). Tables with results provide real numerical data, while alphabet letters point to homogenous groups 
Table 2 Chromosome number and nuclear DNA content of chrysanthemum cultivars subjected to cryopreservation (LN) and of untreated control plants from in vitro cultures and after acclimatisation to ex vitro conditions

\begin{tabular}{|c|c|c|c|c|}
\hline \multirow[t]{2}{*}{ Material } & \multirow{2}{*}{$\begin{array}{l}\text { Chromosome } \\
\text { number }\end{array}$} & \multicolumn{2}{|c|}{ 2C DNA content } & \multirow[t]{2}{*}{$\mathrm{CV}^{1}[\%]$} \\
\hline & & Mbp & $\mathrm{pg} \pm \mathrm{SD}$ & \\
\hline \multicolumn{5}{|c|}{ Lady orange } \\
\hline \multicolumn{5}{|c|}{ In vitro } \\
\hline Control & n.t. & 17,262 & $17.65 \pm 0.12 \mathrm{a}$ & $4.75 \pm 0.80$ \\
\hline LN & n.t. & 17,281 & $17.67 \pm 0.15 a$ & $4.62 \pm 0.74$ \\
\hline \multicolumn{5}{|l|}{ Ex vitro } \\
\hline Control & 54 & 17,526 & $17.92 \pm 0.20 \mathrm{a}$ & $3.23 \pm 0.56$ \\
\hline $\mathrm{LN}$ & 54 & 17,526 & $17.92 \pm 0.14 \mathrm{a}$ & $3.53 \pm 0.51$ \\
\hline Mean & & 17,399 & $17.80 \pm 0.21$ & \\
\hline \multicolumn{5}{|c|}{ Lady salmon } \\
\hline \multicolumn{5}{|l|}{ In vitro } \\
\hline Control & n.t. & 17,672 & $18.07 \pm 0.15 \mathrm{a}$ & $4.53 \pm 0.77$ \\
\hline LN & n.t. & 17,672 & $18.07 \pm 0.15 \mathrm{a}$ & $4.92 \pm 0.77$ \\
\hline \multicolumn{5}{|l|}{ Ex vitro } \\
\hline Control & 54 & 17,976 & $18.38 \pm 0.09 \mathrm{a}$ & $4.95 \pm 0.68$ \\
\hline $\mathrm{LN}$ & 54 & 17,907 & $18.31 \pm 0.15 \mathrm{a}$ & $4.80 \pm 0.70$ \\
\hline Mean & & 17,807 & $18.19 \pm 0.23$ & \\
\hline \multicolumn{5}{|l|}{ Richmond } \\
\hline \multicolumn{5}{|l|}{ In vitro } \\
\hline Control & n.t. & 18,338 & $18.75 \pm 0.19 a$ & $5.03 \pm 0.66$ \\
\hline $\mathrm{LN}$ & n.t. & 18,328 & $18.74 \pm 0.12 a$ & $4.91 \pm 0.57$ \\
\hline \multicolumn{5}{|l|}{ Ex vitro } \\
\hline Control & 54 & 18,484 & $18.90 \pm 0.26 \mathrm{a}$ & $4.89 \pm 0.65$ \\
\hline $\mathrm{LN}$ & 54 & 18,523 & $18.94 \pm 0.24 \mathrm{a}$ & $4.83 \pm 0.80$ \\
\hline Mean & & 18,418 & $18.45 \pm 0.22$ & \\
\hline
\end{tabular}

Means \pm standard deviations in columns marked with the same letter do not differ significantly at $P=0.05$; SD - standard deviation; ${ }^{1} C V$ variation coefficient of the G0/G1 peaks; n.t. not tested

having made the statistical calculations based on transformed data.

\section{Results}

\section{Evaluation of plant (cyto)genetic stability}

No changes in the nuclear DNA content were reported within the cultivars tested during both in vitro and ex vitro growth of the plants (Table 2). The relative amount of DNA reached $17.8-18.45 \mathrm{pg} / 2 \mathrm{C}$, depending on the cultivar. All plants remained hexaploids with 54 chromosomes in the root tips (Fig. 1).

The ten primers yielded a total of 2519 to 4255 scorable bands, depending on the cultivar. RAPD markers generated more products (18.0-20.4 loci per primer) than ISSRs (10.7-15.6 loci per primer). No polymorphisms were found within the untreated controls of all cultivars tested. However, by applying RAPD and ISSR markers it was possible to detect a total of 18 polymorphic loci within cryopreservation-recovered 'Lady Orange' (10\% of their entire number) and 1 within 'Lady Salmon' (0.6\%) (Table 3; Fig. 2). In those two cultivars, polymorphic bands were present in 7.8 and $3.2 \%$ of the plants analysed, respectively. As for 'Richmond', no polymorphisms were detected.

As for 'Lady Orange' RAPD analysis, four clusters could be distinguished. According to the UPGMA analysis (Fig. 3), confirmed by PCoA (Fig. 4), the most genetically distinct were genotypes LO21 and LO36 with the variation of approximately $10 \%$ and $8 \%$, respectively. Another group of genetic difference of about $4 \%$ included two individuals: LO4 and LO20. The ISSR markers detected genetic variation (of 15\%) only with LO21 genotype. As for 'Lady Salmon' RAPD, the UPGMA analysis showed over $2 \%$ variation within LS6 genotype, while no variation was detected by the ISSR markers. Also 100\% homology of 'Richmond' individuals was confirmed by both molecular markers.

According to the AMOVA test, variation was observed only within the groups included, i.e. control and cryopreserved, but not between them.

\section{Evaluation of vegetative growth}

An influence of cryopreservation on length of the shoots was found (Table 4). Chrysanthemums 'Lady Salmon' and 'Richmond' recovered from cryopreserved shoot tips were significantly smaller than the untreated control (by 9.1 and $5.3 \mathrm{~cm}$, respectively). However, this variation was not observed until shading of the plants (data not shown). Despite the change in length, no difference in leaves (nodes) number was reported in the two cultivars. Only in 'Lady Orange' there was no influence of cryopreservation on the shoot length, but those plants produced more leaves/nodes after storage in LN. Consequently, the internodes of all the cryopreservation-derived plants were shorter (at about 13\%) than those of the control.

Plants recovered from the cryopreserved shoot tips of all three cultivars had a lower chlorophyll content in leaves (CCI -21) as compared to the control (CCI - 29.5) (Table 4). Therefore, their leaves were of lighter colour according to the RHSCC catalogue, especially in 'Lady Salmon'.

There was a significant influence of cryopreservation on the leaves size in accordance to their topophysical position on the plant's stem (Table 5). In LN-recovered 'Lady Salmon' plants, centrally-located leaves were narrower than the control samples, while bottom and central leaves of cryopreservation-derived chrysanthemum 'Richmond' were shorter in comparison to the untreated control. As for 'Lady Orange' plants recovered after cryopreservation, all leaves 

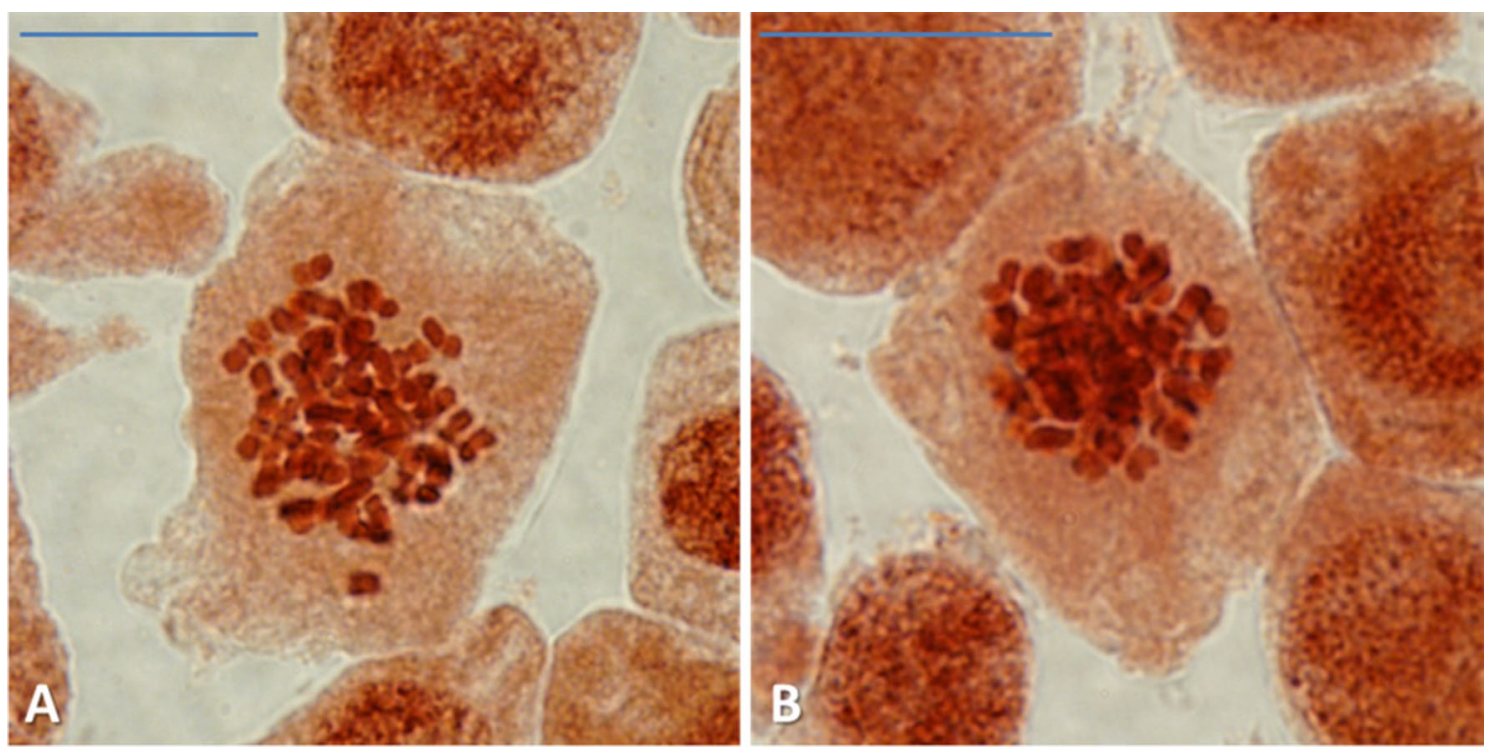

Fig. 1 Chromosomes visualisation of chrysanthemum 'Richmond' cultivated ex vitro-control (a) and after cryopreservation (b, magnification $100 \times$, bar $=20 \mu \mathrm{m})$

Table 3 Characteristic of molecular products obtained from the plants analysed after applying RAPD and ISSR markers

\begin{tabular}{|c|c|c|c|c|c|c|c|c|c|}
\hline \multirow[t]{2}{*}{ Marker type } & \multirow[t]{2}{*}{ No. of bands } & \multicolumn{2}{|c|}{ No. of loci } & \multicolumn{2}{|c|}{$\begin{array}{l}\text { No. of monomorphic } \\
\text { loci }\end{array}$} & \multicolumn{2}{|c|}{ No. of polymorphic loci } & \multirow{2}{*}{$\begin{array}{l}\text { Polymor- } \\
\text { phic loci } \\
{[\%]}\end{array}$} & \multirow[t]{2}{*}{$\begin{array}{l}\text { No. and \% of plant } \\
\text { with polymorphism }\end{array}$} \\
\hline & & Total & $\begin{array}{l}\text { Mean from a } \\
\text { single primer }\end{array}$ & Total & $\begin{array}{l}\text { Mean from a } \\
\text { single primer }\end{array}$ & $\begin{array}{l}\text { Total (poly- } \\
\text { morphic/spe- } \\
\text { cific) }\end{array}$ & $\begin{array}{l}\text { Mean from a } \\
\text { single primer }\end{array}$ & & \\
\hline \multicolumn{10}{|l|}{ Lady orange } \\
\hline RAPD & 2319 & 102 & 20.4 & 90 & 18.0 & $12(3 / 9)$ & 2.4 & 11.8 & $4(7.8 \%)$ \\
\hline ISSR & 1936 & 78 & 15.6 & 72 & 14.4 & $6(4 / 2)$ & 1.2 & 7.7 & $1(2.0 \%)$ \\
\hline$\Sigma$ & 4255 & 180 & 36.0 & 162 & 32.4 & $18(7 / 11)$ & 3.6 & 10.0 & 4 \\
\hline \multicolumn{10}{|l|}{ Lady salmon } \\
\hline RAPD & 1463 & 93 & 18.6 & 92 & 18.4 & $1(0 / 1)$ & 0.2 & 1.1 & $1(3.2 \%)$ \\
\hline ISSR & 1056 & 66 & 13.2 & 66 & 13.2 & 0 & 0.0 & 0.0 & $0(0.0 \%)$ \\
\hline$\Sigma$ & 2519 & 159 & 31.8 & 158 & 31.6 & $1(0 / 1)$ & 0.2 & 0.6 & 1 \\
\hline \multicolumn{10}{|l|}{ Richmond } \\
\hline RAPD & 1890 & 90 & 18.0 & 90 & 18.0 & 0 & 0.0 & 0.0 & $0(0.0 \%)$ \\
\hline ISSR & 672 & 32 & 10.7 & 32 & 10.7 & 0 & 0.0 & 0.0 & $0(0.0 \%)$ \\
\hline$\Sigma$ & 2652 & 122 & 28.7 & 122 & 28.7 & 0 & 0.0 & 0.0 & $0(0.0 \%)$ \\
\hline
\end{tabular}

(bottom, centrally- and upper-located) were significantly smaller and narrower than the control ones.

\section{Evaluation of generative growth}

The control and LN-recovered plants within cultivars initiated flowering and bud colouration at the same time ('Lady Orange': 137-139 days, 'Lady Salmon': 113-118 days and 'Richmond': 138-142 days after acclimatisation) (Fig. 5).
Cryopreservation did not affect the subsequent flower development in most cases. However, 'Lady Salmon' plants recovered after cryopreservation opened their inflorescences slower (maximal diameter achieved 11.1 days after bud coloration) than the control ( 7.9 days). A revers phenomenon was observed when analysing the pace of flower fading. Control 'Lady Salmon' chrysanthemums lasted 18 days from full flowering to fading of the last flower whorl (the whorls withered one after another). As for the plants recovered after 


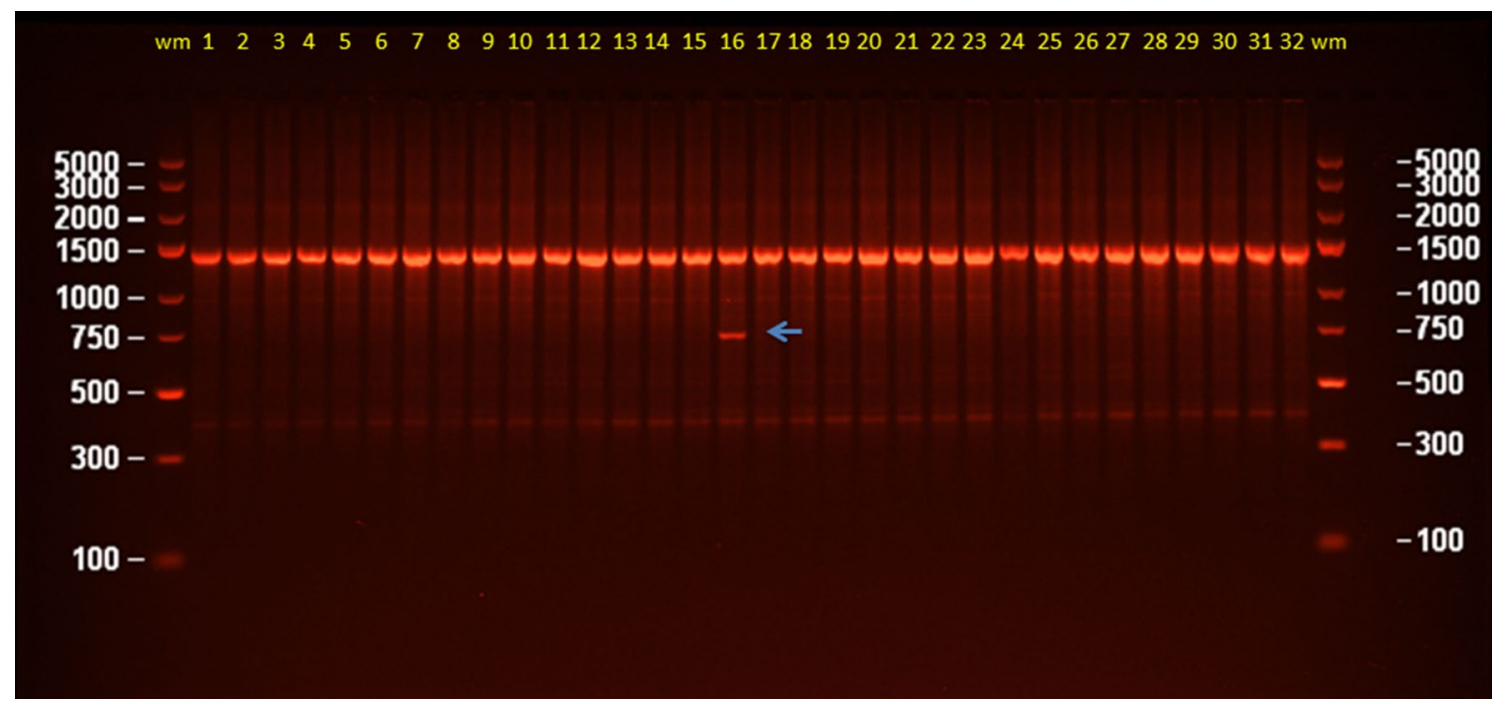

Fig. 2 Example RAPD band profiles of 'Lady Salmon' received as a result of electrophoresis of the DNA amplification products obtained with the R-A primer. Outermost lanes (wm) are DNA bp weight

cryopreservation, the inflorescences were fading simultaneously on the entire surface (all whorls at the same time). It was observed that cryopreservation extended the entire 'Richmond' production cycle, from acclimatisation until flower fading, by three days (164 days) in comparison to the control (161 days). markers; $1,2,3, . .-$ are numbers of plants (1-10 control plants, $11-32$ plants recovered after cryopreservation); arrow points to the profile which differs from the reference

No influence of cryopreservation on the inflorescence diameter, fresh weight and length of ray florets of all three cultivars was reported (Table 6). Also the colour of the inflorescences remained unchanged after storage of explants in LN (Fig. 6).

Phenotypical observation was confirmed by the biochemical assay (Table 7). In 'Lady Orange' and 'Lady Salmon'
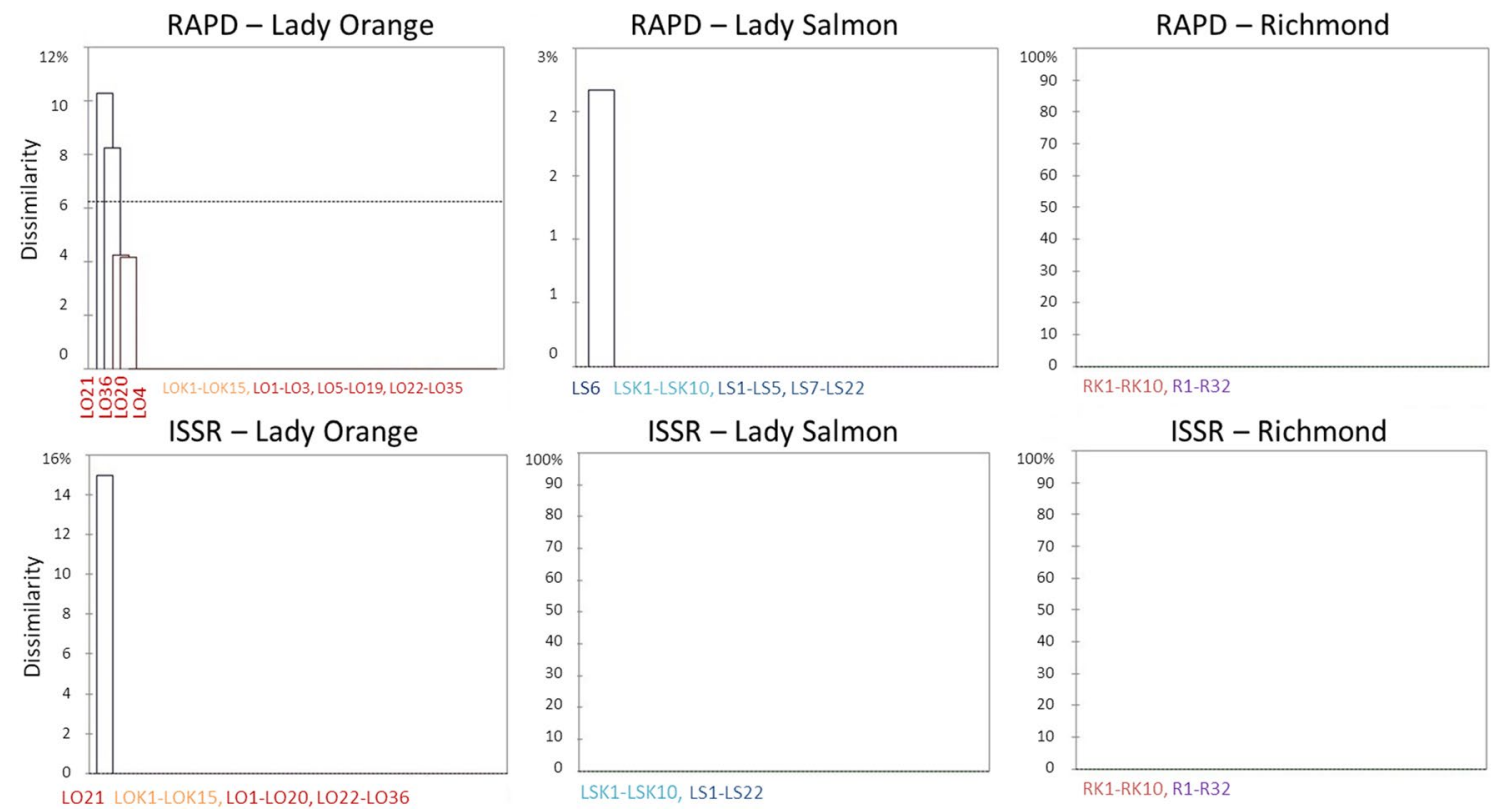

Fig. 3 UPGMA dendrograms of genetic differentiation of control and cryopreserved chrysanthemums 'Lady Orange' (LO), 'Lady Salmon' (LS) and 'Richmond' (R) obtained from RAPD and ISSR analysis;
LOK, LSK, RK—control plants; LO1-LO36, LS1-LS22. R1-R32plants after cryopreservation 

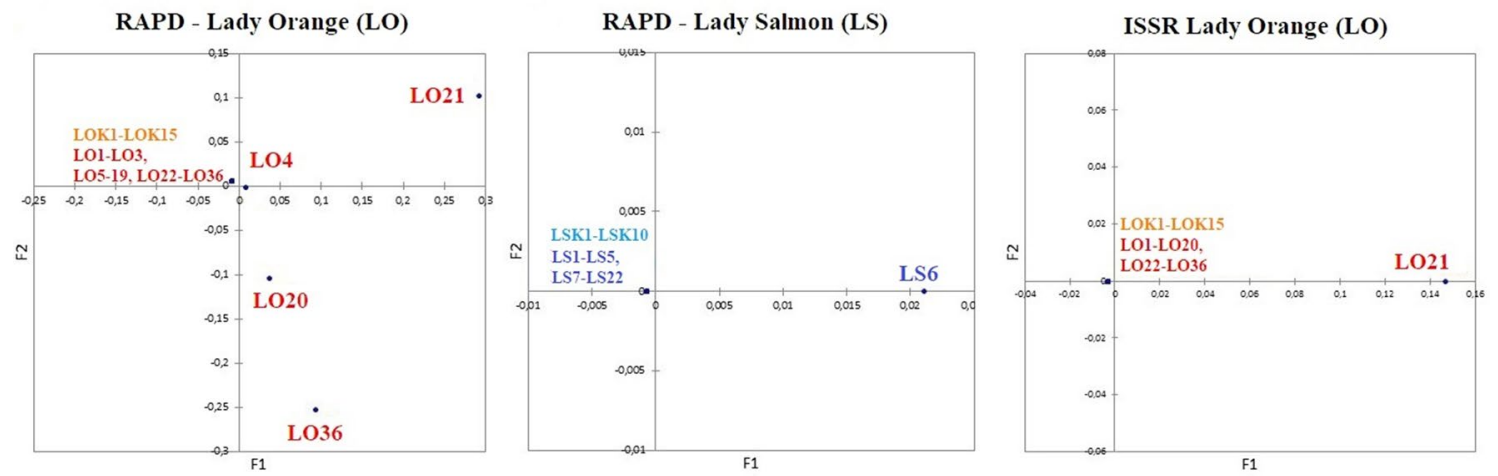

Fig. 4 Graphs of principal coordinates analysis (PCoA) of control and cryopreserved chrysanthemums 'Lady Orange' (LO) and 'Lady Salmon' (LS) obtained from RAPD and ISSR analysis; LOK, LSK—control plants; LO1-LO36, LS1-LS22—plants after cryopreservation

Table 4 Influence of cryopreservation (LN) on the chrysanthemum plants habit and chlorophyll content in leaves during ex vitro growth

\begin{tabular}{lcll}
\hline Treatment & Lady orange & Lady salmon & Richmond \\
\hline Shoot length [cm] & & & \\
Control & $45.5 \pm 1.4 \mathrm{a}$ & $65.8 \pm 0.9 \mathrm{a}$ & $37.6 \pm 0.8 \mathrm{a}$ \\
LN & $42.5 \pm 0.8 \mathrm{a}$ & $56.7 \pm 1.6 \mathrm{~b}$ & $32.3 \pm 0.7 \mathrm{~b}$ \\
Leaf number & & & \\
Control & $28.1 \pm 0.7 \mathrm{a}$ & $30.3 \pm 0.7 \mathrm{a}$ & $45.6 \pm 0.4 \mathrm{a}$ \\
LN & $31.6 \pm 0.3 \mathrm{~b}$ & $30.3 \pm 0.5 \mathrm{a}$ & $45.5 \pm 1.0 \mathrm{a}$ \\
Internode length [cm] & & \\
Control & $1.6 \pm 0.0 \mathrm{a}$ & $2.2 \pm 0.0 \mathrm{a}$ & $0.8 \pm 0.0 \mathrm{a}$ \\
LN & $1.4 \pm 0.0 \mathrm{~b}$ & $1.9 \pm 0.0 \mathrm{~b}$ & $0.7 \pm 0.0 \mathrm{~b}$ \\
Chlorophyll content [CCI] & & \\
Control & $34.0 \pm 0.8 \mathrm{a}$ & $30.1 \pm 1.0 \mathrm{a}$ & $22.0 \pm 1.0 \mathrm{a}$ \\
LN & $24.1 \pm 0.5 \mathrm{~b}$ & $19.2 \pm 0.6 \mathrm{~b}$ & $19.0 \pm 0.5 \mathrm{~b}$ \\
Leaf colour [RHSCC code] & & \\
Control & $147 \mathrm{~A}$ & $147 \mathrm{~A}$ & $147 \mathrm{~A}$ \\
LN & $137 \mathrm{~A}$ & $137 \mathrm{C}$ & $137 \mathrm{~A}$ \\
\hline
\end{tabular}

Means \pm standard errors in columns marked with the same letter do not differ significantly at $P=0.05$

CCI chlorophyll content index

inflorescences, the presence of flavonols (data not shown) and carotenoids was detected. Their concentration was equal in the control and cryopreservation-recovered plants, and reached: $2.2-2.3 \mathrm{mg} \cdot \mathrm{g}^{-1}$ ('Lady Orange') and $1.1-1.3 \mathrm{mg} \cdot \mathrm{g}^{-1}$ ('Lady Salmon'). No detectable amounts of anthocyanins were present in the cultivars of the Lady group. They were found in 'Richmond' chrysanthemum, but there was also no difference between the control and LN-recovered plants (17.1 and $16.9 \mathrm{mg} \cdot \mathrm{g}^{-1}$ cyjanidin, respectively).

\section{Discussion}

\section{Effect of cryopreservation on the (cyto)genetic stability of recovered plants}

In the case of LN storage, a major concern is the genetic integrity of plants produced from cryopreserved material. The applied here encapsulation-dehydration procedure is promising with chimeras, as it allows to avoid the cytotoxic and mutagenic effect of plant vitrification solutions, especially those based on DMSO (dimethyl sulfoxide), used in other cryopreservation techniques, e.g. droplet-vitrification or encapsulation-vitrification (Ciringer et al. 2018).

Usually, there is no influence of cryopreservation on the nuclear DNA content of the LN-stored plant samples (Wang et al. 2014; Bi et al. 2016; Li et al. 2016). Although, Mikuła et al. (2009) reported that cryopreservation led to a nuclear DNA content decrease in the LN-derived gametophytes and recovered from them sporophytes of Cyathea australis (R. BR.) Domin. As for Gentiana tibetica King ex Hook. F. and G. cruciata L., cryopreservation did not affect the ploidy level, however, there was a difference in DNA content depending on the plant material; leaves of regenerants and proembryogenic mass (Mikuła et al. 2008). The present results support the concept that cryopreservation can maintain cytogenetic stability of the LN-stored plants, if other steps of in vitro tissue culture before and after cryostorage are properly controlled. There was also no change in chromosome number observed in the chrysanthemum cultivars tested. Cryopreservation rarely affects the number of chromosomes, their size, localisation of the centromere, etc. (Kulus and Zalewska 2014). However, with Fragaria $\times$ ananasa Duchesne, despite no changes in ploidy level, a change in chromosome number was reported (Hao et al. 2002).

Although several cryopreservation protocols have been described for chrysanthemum, only a few studies assessed 
Table 5 Influence of cryopreservation (LN) on the length of leaves during ex vitro growth with regard to their topophysical location

\begin{tabular}{|c|c|c|c|c|c|c|}
\hline \multirow[t]{2}{*}{ Treatment } & \multicolumn{2}{|l|}{ Lady orange } & \multicolumn{2}{|l|}{ Lady salmon } & \multicolumn{2}{|l|}{ Richmond } \\
\hline & Leaf length $[\mathrm{cm}]$ & Leaf width $[\mathrm{cm}]$ & Leaf length $[\mathrm{cm}]$ & Leaf width $[\mathrm{cm}]$ & Leaf length $[\mathrm{cm}]$ & Leaf width $[\mathrm{cm}]$ \\
\hline \multicolumn{7}{|c|}{ Bottom leaves } \\
\hline Control & $9.4 \pm 0.3 \mathrm{a}$ & $7.2 \pm 0.2 \mathrm{a}$ & $10.4 \pm 0.1 \mathrm{a}$ & $6.2 \pm 0.3 \mathrm{a}$ & $9.8 \pm 0.4 \mathrm{a}$ & $8.4 \pm 0.3 \mathrm{a}$ \\
\hline $\mathrm{LN}$ & $6.8 \pm 0.3 b$ & $5.3 \pm 0.2 b$ & $9.7 \pm 0.3 \mathrm{a}$ & $7.0 \pm 0.2 \mathrm{a}$ & $9.0 \pm 0.2 \mathrm{~b}$ & $8.3 \pm 0.2 \mathrm{a}$ \\
\hline \multicolumn{7}{|c|}{ Central leaves } \\
\hline Control & $10.3 \pm 0.3 \mathrm{a}$ & $6.3 \pm 0.2 \mathrm{a}$ & $9.6 \pm 0.4 \mathrm{a}$ & $8.2 \pm 0.3 \mathrm{a}$ & $11.4 \pm 0.4 \mathrm{a}$ & $7.2 \pm 0.2 \mathrm{a}$ \\
\hline $\mathrm{LN}$ & $8.9 \pm 0.2 \mathrm{~b}$ & $5.6 \pm 0.1 \mathrm{~b}$ & $9.3 \pm 0.2 \mathrm{a}$ & $6.5 \pm 0.2 b$ & $10.1 \pm 0.2 b$ & $6.8 \pm 0.1 \mathrm{a}$ \\
\hline \multicolumn{7}{|c|}{ Upper leaves } \\
\hline Control & $2.6 \pm 0.1 \mathrm{a}$ & $1.0 \pm 0.09 \mathrm{a}$ & $4.2 \pm 0.3 \mathrm{a}$ & $1.8 \pm 0.1 \mathrm{a}$ & $1.6 \pm 0.1 \mathrm{a}$ & $0.5 \pm 0.1 \mathrm{a}$ \\
\hline LN & $2.2 \pm 0.1 \mathrm{~b}$ & $0.7 \pm 0.06 \mathrm{~b}$ & $4.2 \pm 0.2 \mathrm{a}$ & $2.1 \pm 0.1 \mathrm{a}$ & $1.7 \pm 0.1 \mathrm{a}$ & $0.6 \pm 0.1 \mathrm{a}$ \\
\hline
\end{tabular}

Means \pm standard errors in columns marked with the same letter do not differ significantly at $P=0.05$

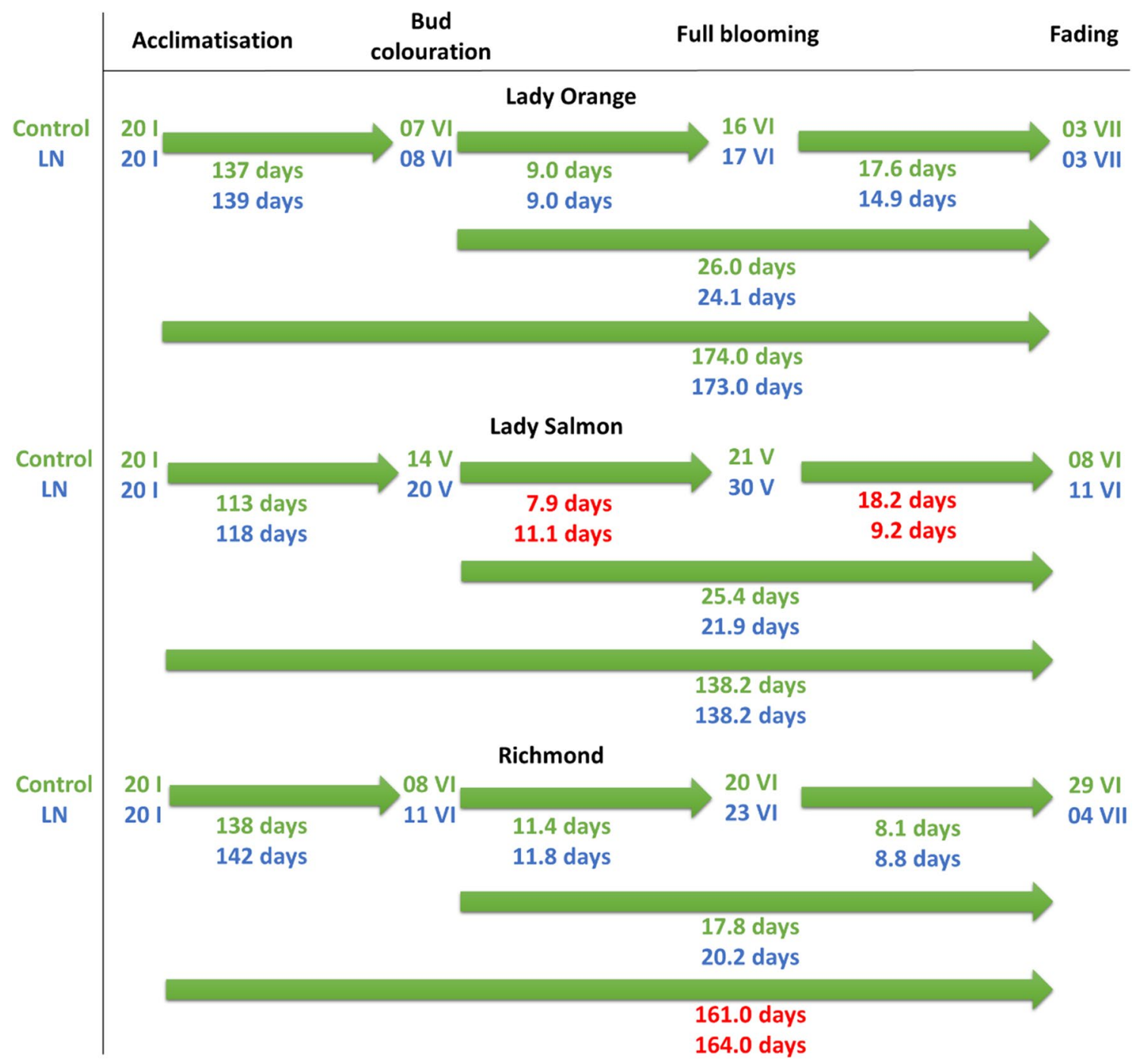

Fig. 5 Schematic presentation of the effect of cryopreservation (LN) on the time and length of flowering of the chrysanthemum cultivars studied. Red font indicates significant differences at $P=0.05$. (Color figure online) 
Table 6 Influence of cryopreservation (LN) on the physical parameters of chrysanthemum inflorescences

\begin{tabular}{|c|c|c|c|}
\hline Treatment & Lady orange & Lady salmon & Richmond \\
\hline \multicolumn{4}{|c|}{ Fresh weight $[\mathrm{g}]$} \\
\hline Control & $6.0 \pm 0.6 \mathrm{a}$ & $12.0 \pm 0.8 \mathrm{a}$ & $8.9 \pm 0.8 \mathrm{a}$ \\
\hline $\mathrm{LN}$ & $6.5 \pm 0.4 \mathrm{a}$ & $12.7 \pm 0.4 \mathrm{a}$ & $8.8 \pm 0.4 \mathrm{a}$ \\
\hline \multicolumn{4}{|c|}{ Diameter $[\mathrm{cm}]$} \\
\hline Control & $5.8 \pm 0.2 \mathrm{a}$ & $7.8 \pm 0.2 \mathrm{a}$ & $6.4 \pm 0.2 \mathrm{a}$ \\
\hline $\mathrm{LN}$ & $6.0 \pm 0.1 \mathrm{a}$ & $8.4 \pm 0.1 \mathrm{a}$ & $6.4 \pm 0.1 \mathrm{a}$ \\
\hline \multicolumn{4}{|c|}{ Ray floret length $[\mathrm{cm}]$} \\
\hline Control & $2.3 \pm 0.1 \mathrm{a}$ & $2.8 \pm 0.1 \mathrm{a}$ & $2.8 \pm 0.1 \mathrm{a}$ \\
\hline $\mathrm{LN}$ & $2.3 \pm 0.0 \mathrm{a}$ & $3.0 \pm 0.1 \mathrm{a}$ & $2.8 \pm 0.1 \mathrm{a}$ \\
\hline \multicolumn{4}{|c|}{ Flower colour [RHSCC code] } \\
\hline Control & Orange $(6 \mathrm{~A})$ & Salmon (11B) & Purple (61B) \\
\hline $\mathrm{LN}$ & Orange (6A) & Salmon (11B) & Purple (61B) \\
\hline
\end{tabular}

Means \pm standard errors in columns marked with the same letter do not differ significantly at $P=0.05$

RHSCC Royal horticulture society colour chart

the genetic fidelity in the recovered plants (Martín and González-Benito 2005; Martín et al. 2011; Wang et al. 2014; Bi et al. 2016). The results obtained in this study indicate a low level of genetic variability within just a few plants tested. Therefore, the described here encapsulationdehydration cryopreservation procedure of chrysanthemum shoot tips seems to be more effective than the one proposed by Martín et al. (2011). In their study, RAPD markers detected a permanent variation already after the explants preculture on the medium with an increased (up to $0.3 \mathrm{M}$ ) sucrose content ( $5.8 \%$ polymorphism rate), while the AFLP (amplified fragments length polymorphisms)
Table 7 Influence of cryopreservation (LN) on the anthocyanins and carotenoid content in ray flowers

\begin{tabular}{llll}
\hline Treatment & Lady orange & Lady salmon & Richmond \\
\hline & Anthocyanins $\left[\mathrm{mg} \mathrm{g}^{-1}\right]$ & & \\
Control & - & - & $17.1 \pm 0.6 \mathrm{a}$ \\
LN & - & - & $16.9 \pm 0.3 \mathrm{a}$ \\
& Carotenoids $\left[\mathrm{mg} \mathrm{g}^{-1}\right]$ & & \\
Control & $2.2 \pm 0.5 \mathrm{a}$ & $1.1 \pm 0.1 \mathrm{a}$ & - \\
LN & $2.3 \pm 0.3 \mathrm{a}$ & $1.3 \pm 0.0 \mathrm{a}$ & - \\
\hline
\end{tabular}

Means \pm standard errors in columns marked with the same letter do not differ significantly at $P=0.05$; “-” pigment absent

analysis revealed an even greater range of variation $(40.1 \%$ polymorphism rate), which intensified during the following cryopreservation steps. This phenomenon resulted from the osmotic shock and indicates that genetic variation may occur throughout the cryopreservation process, and the low temperature itself is not the only stress risk of the procedure. A similar low genomic variation, at the level of 5\%, was also reported in LN-stored Mentha $\times$ piperita L. (Martín et al. 2015) and Hladnikia pastinacifolia Rchb. (Ciringer et al. 2018). On the other hand, Bi et al. (2016) found no polymorphic bands revealed by ISSR and RAPD markers in the chrysanthemums treated with droplet-vitrification technique. Similarly, those two marker types did not detect any polymorphic loci in the plants of Vitis vinifera L. 'Cabernet Sauvignon', recovered from shoot tips that were cryopreserved via droplet-vitrification technique (Bi et al. 2018). According to Schäfer-Menuhr et al. (1997), in order to meet the demands of the market, it is required to maintain the most essential characteristics
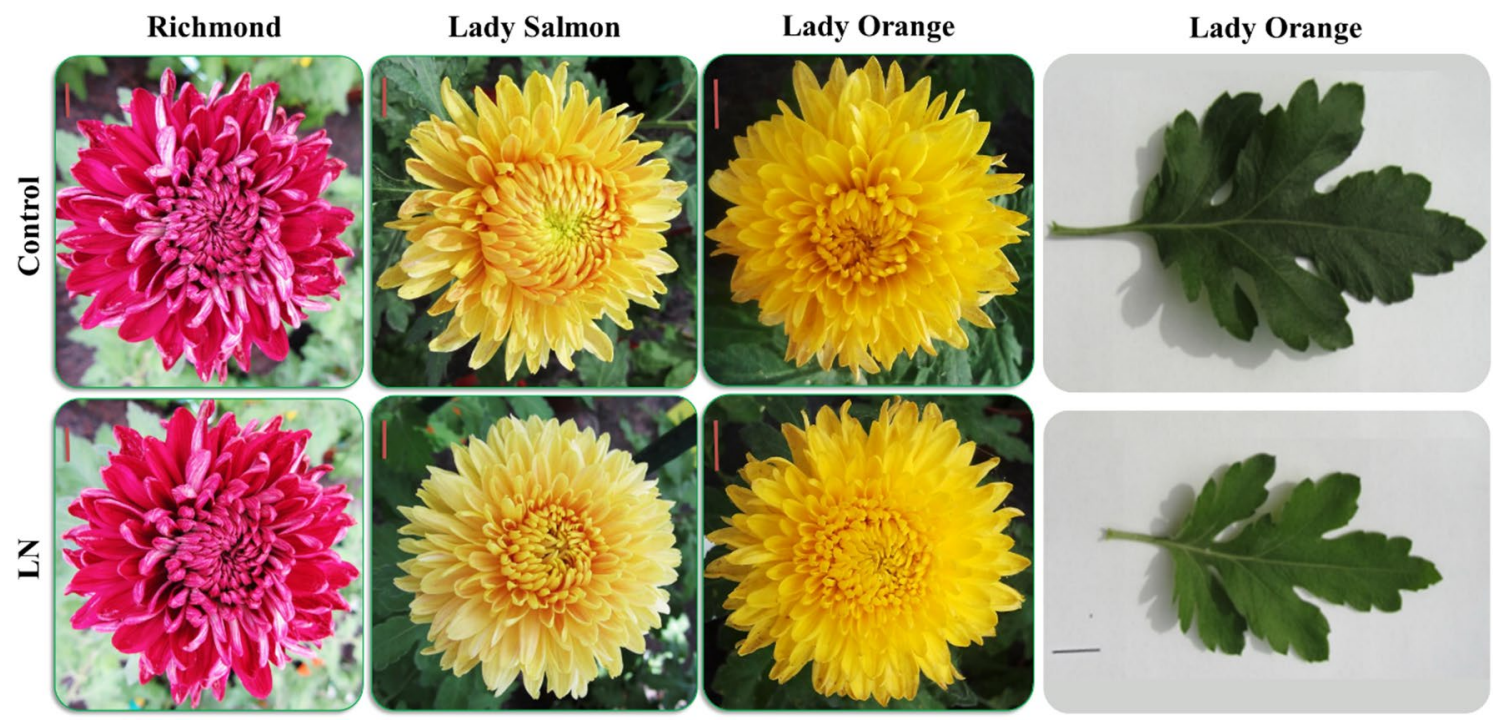

Fig. 6 Comparison of inflorescences and bottom leaves of control and cryopreservation-recovered (LN) chrysanthemums; bar $=1 \mathrm{~cm}$ 
of the cultivar stored in LN, which allow for its further cultivation, reproduction or breeding. Whereas molecular markers detect changes in DNA sequence, which not necessarily must have an influence on the phenotype as in the present study. The observed here minor DNA sequence variation could occur in the non-coding DNA fragments and is likely caused by other, in vitro-related, steps rather than storage in liquid nitrogen. Since different DNA marker types could detect polymorphisms in different genomic regions, the use of two marker systems gave reliable results and indicate that the described encapsulationdehydration protocol can be considered safe to maintain genetic integrity in chrysanthemum chimeras. Moreover, it was found that RAPD markers are more sensitive in detecting DNA sequence variation in chrysanthemum than ISSR markers.

\section{Effect of cryopreservation on the vegetative growth of recovered plants}

Knowledge about the effect of cryopreservation on the vegetative growth of regenerated plants is quite limited, especially those transferred to ex vitro conditions. Tavazza et al. (2013) and Kulus et al. (2018b) found that growth of shoots of three artichoke and chrysanthemum cultivars, recovered from cryopreserved shoot tips, was slower than the control at the first subculture. On the other hand, no such effect was reported with Vitis spp. (Bi et al. 2018). Bi et al. (2016) found no alternations of vegetative growth or morphologies of leaf of chrysanthemum 'Hangju' recovered after storage in LN. In the present study, cryopreservation affected the glasshouse performance of plants, which were shorter and had a reduced leaves size in comparison to the control. The specific mechanism for altered vegetative growth in the plants is unclear and could have an epigenetic origin (Matsumoto 2017). In general, those changes can be considered positive from the horticultural point of view, since plants with shorter internodes are easier in caring and harvesting. Smaller leaves, on the other hand, have a reduced transpiration surface, which results in a lower water demand of the plant and potentially longer vase life. Furthermore, such plants are easier in sorting and packing. It was also found, that cryopreservation-derived chrysanthemums had a reduced chlorophyll content. Similar results were observed with LN-stored chrysanthemum cell lines and tomato shoot tips by Hitmi et al. (1997) and Zevallos et al. (2013), respectively. A lowered chlorophyll content may be explained by the fact, that it is the most labile pigment within the plant body (Van Assche and Clijsters 1990). During stress, a decline in chlorophyll content may be found due to inhibition of important enzymes, such as $\delta$-aminolevulinic acid dehydratase and protochlorophyllide reductase, related to its biosynthesis. Moreover, alternation of chlorophyll native structure, caused by dehydration necessary for explants survival in LN or significant temperature change, may accelerate the degradation of the pigment and result in a change of leaf colour (Van Assche and Clijsters 1990).

\section{Effect of cryopreservation on the generative growth}

The quality and parameters of flowers are the most important aspects when evaluating cultivars of ornamental plants (Reddy et al. 2016). In the present research we analysed, for the first time, the influence of cryopreservation on the time and period of chrysanthemum flowering. Despite flower bud initiation and colouration occurred in the same time within the cryopreservation-recovered and control plants of all three cultivars tested, the cryopreservation-derived 'Lady Salmon' chrysanthemums opened their inflorescences slower than the control. This is a positive change, since when buying flowers, consumers are choosing the ones, which are at an early developmental stage and expect them to have a long vase life (Jindal et al. 2018).

Bi et al. (2016) reported no change in flower dimeter, number, fresh and dry weight of chrysanthemum 'Hangju' recovered after storage in LN. Similarly in the present study there was no change in flower weight, diameter and length of ray florets.

Analysis of biochemical compounds is important, especial for plants of medicinal use like Chrysanthemum $\times$ grandiflorum (Kalia et al. 2016). The impact of cryopreservation on the biosynthetic activity may be explant-dependant. For example, Hitmi et al. (1997) reported that the ability to synthesize pyrethrin was significantly improved in cryopreserved cell lines of $C$. cinerariaefolium Vis. On the other hand, cryopreservation did not change the content of pyrethrin in the plants recovered from cryopreserved shoot tips (Hitmi et al. 2000). Similarly, in the present study, no difference in anthocyanins and carotenoids concentration in the inflorescences of control and cryopreservation-derived chrysanthemums was found confirming that shoot tips are more stable than cell cultures and, therefore, recommended for preservation of plant genetic resources.

The maintenance of the original colour of the two tested chimeric cultivars in the present research confirms the protection of both tunica layers and underlines the effectiveness of the proposed cryopreservation procedure (Kulus et al. 2018a). Also, maintaining the original size, shape, and colour of the purple-flowering 'Richmond' chrysanthemum, which is one of the most susceptible cultivars in terms of mutation occurrence and change of flower colour, may be considered a full success. 


\section{Summary}

In the past it was not possible to completely maintain the stability of chrysanthemum stored in LN, either by using classical/two-step freezing (Fukai and Oe 1990; Fukai et al. 1994), as well as by modern vitrification-based techniques (Martín and González-Benito 2009; Martín et al. 2011). Our study showed that the encapsulation-dehydration technique based on 14-day preculture with $0.09 \mathrm{M}$ sucrose and $10 \mu \mathrm{M}$ ABA, followed by 4-day osmotic dehydration and 3 -hour desiccation is optimal for the shoot tip cryopreservation of three chrysanthemum cultivars. Although this cryopreservation protocol results in some changes at the DNA-sequence level and affects the vegetative growth of plants, it does not disturb their chimeric structure. These results illustrate the practicability of a cryopreservation method that completely protects the chrysanthemum chimera identity and, therefore, it can be used to create a gene bank of the chrysanthemum cultivars, including solid mutants and periclinal chimeras.

Acknowledgement Project supported by the Polish Ministry of Science and Higher Education ("Iuventus Plus", No IP2014023373).

Author contribution DK and AM conceived and designed research. DK, MR and MS conducted the experiments. DK and AM wrote the manuscript.

\section{Compliance with ethical standards}

Conflict of interest The authors declare that they have no conflict of interest.

Open Access This article is distributed under the terms of the Creative Commons Attribution 4.0 International License (http://creativeco mmons.org/licenses/by/4.0/), which permits unrestricted use, distribution, and reproduction in any medium, provided you give appropriate credit to the original author(s) and the source, provide a link to the Creative Commons license, and indicate if changes were made.

\section{References}

Bi W-L, Pan C, Liu J, Wang Q-C (2016) Greenhouse performance, genetic stability and biochemical compounds in Chrysanthemum morifolium 'Hangju' plants regenerated from cryopreserved shoot tips. Acta Physiol Plant 38:268. https://doi.org/10.1007/s1173 8-016-2288-2

Bi W-L, Hao X-Y, Cui Z-H, Volk GM, Wang Q-C (2018) Droplet-vitrification cryopreservation of in vitro-grown shoot tips of grapevine (Vitis spp.). In Vitro Cell Dev Biol 54(6):590-599

Chatterjee A, Saha D, Niemann H, Gryshkov O, Glasmacher B, Hofmann N (2017) Effects of cryopreservation on the epigenetic profile of cells. Cryobiol 74:1-7. https://doi.org/10.1016/j.cryob iol.2016.12.002
Ciringer T, Martín C, Šajna N, Kaligarič M, Ambrožič-Dolinšek J (2018) Cryopreservation of an endangered Hladnikia pastinacifolia Rchb. by shoot tip encapsulation-dehydration and encapsulation-vitrification. In Vitro Cell Dev Biol 54(6):565-575

de Oliveira Prudente D, Paiva R (2017) Plant cryopreservation: biochemical aspects. J Cell Dev Biol 1:1-2

Doležel J, Bartoš J, Voglmayr H, Greilhuber J (2003) Nuclear DNA content and genome size of trout and human. Cytometry A 51:127-128. https://doi.org/10.1002/cyto.a.10013

Fukai S, Oe M (1990) Morphological observations of chrysanthemum shoot tips cultured after cryoprotection and freezing. J Jap Soc Hortic Sci 59(2):383-387

Fukai S, Goi M, Tanaka M (1994) The chimeric structure of the apical dome of chrysanthemum (Dendranthema grandiflorum (Ramat.) Kitam.) is affected by cryopreservation. Sci Hortic 57:347-351. https://doi.org/10.1016/0304-4238(94)90117-1

Guan Z, Wu D, Song A, Chen F, Chen S, Fang W (2017) A highly sensitive method for the detection of chrysanthemum virus B. Electr J Biotechnol 26:64-68. https://doi.org/10.1016/j.ejbt.2017.01.003

Hao YJ, You CX, Deng XX (2002) Analysis of ploidy and the patterns of amplified fragment length polymorphism and methylation sensitive amplified polymorphism in strawberry plants recovered from cryopreservation. CryoLett 23:37-46

Harborne JB (1967) Comparative biochemistry of the flavonoids. Academic Press, London, pp 25-27

Hitmi A, Sallanon H, Barthomeuf C (1997) Cryopreservation of Chrysanthemum cinerariaefolium Vis. cells and its impact factor on their pyrethrin biosynthesis ability. Plant Cell Rep 17:60-64. https ://doi.org/10.1007/s002990050352

Hitmi A, Barthomeuf C, Sallanon H (2000) Cryopreservation of Chrysanthemum cinerariaefolium shoot tips. J Plant Physiol 156:408412. https://doi.org/10.1016/S0176-1617(00)80081-4

Jeon MS, Arun M, Lee S-Y, Kim CK (2015a) Application of encapsulation-vitrification in combination with air dehydration enhances cryotolerance of Chrysanthemum morifolium shoots tips. Sci Hortic 194:91-99. https://doi.org/10.1016/j.scienta.2015.07.035

Jeon MS, Naing AH, Park KI, Kim CK (2015b) The effect of antifreeze protein on the cryopreservation of chrysanthemums. Plant Cell, Tissue Organ Cult 123(3):665-671. https://doi.org/10.1007/s1124 0-015-0852-x

Jerzy M, Borkowska J (2004) Photoperiodic response of pot chrysanthemums in twelve all year-round production cycles. Electr J Pol Agric Univ 7(2):07

Jindal M, Thumar BV, Hallur V (2018) Effect of planting time and pinching on flowering and flower quality of Chrysanthemum $\mathrm{CV}$. Ratlam Sel. J Pharm Phytochem 7(4):390-393

Kalia R, Katnoria JK, Nagpal AK (2016) Antitumor activity of aqueous leaf extracts of Chrysanhemum morifolium R. using Potato Disc Tumor Assay. J Pharm Sci Res 8(11):1262-1265

Kulus D (2015) Application of cryopreservation for chrysanthemum genetic resources conservation. Acta Hortic 1087:225-232. https ://doi.org/10.13140/RG.2.1.2081.6488

Kulus D (2018) Effect of various preculture, pretreatment and recovery conditions on the morphogenetic response of cryopreserved chrysanthemum 'Lady Orange' shoot tips. Turk J Biol 42:76-86. https://doi.org/10.3906/biy-1711-47

Kulus D, Zalewska M (2014) Cryopreservation as a tool used in longterm storage of ornamental species - a review. Sci Hortic 168:88107. https://doi.org/10.1016/j.scienta.2014.01.014

Kulus D, Abratowska A, Mikuła A (2018a) Morphogenetic response of shoot tips to cryopreservation by encapsulation-dehydration in a solid mutant and periclinal chimeras of Chrysanthemum $\times$ grandiflorum/Ramat./Kitam. Acta Physiol Plant 40(1):18

Kulus D, Serocka M, Mikuła A (2018b) Effect of various preculture and osmotic dehydration conditions on cryopreservation efficiency 
and morphogenetic response of chrysanthemum shoot tips. Acta Sci Pol Hort Cult 17(1):139-147. https://doi.org/10.24326/asphc .2018 .1 .13

Lee YG, Popova E, Cui HY, Kim HH, Park SU, Bae CH, Lee SC, Engelmann F (2011) Improved cryopreservation of chrysanthemum (Chrysanthemum morifolium) using droplet-vitrification. CryoLett 32(6):486-497

Lema-Rumińska J, Zalewska M, Sadoch Z (2004) Radiomutants of chrysanthemum (Dendranthema grandiflora Tzvelev) of the Lady group: rAPD analysis of the genetic diversity. Plant Breed 123(3):290-293. https://doi.org/10.1111/j.1439-0523.2004.00996 . $\mathrm{x}$

Li J-W, Li H-H, Wang R-R, Gao X-X, Wang Q-C (2016) Cryopreservation for retaining morphology, genetic integrity, and foreign genes in transgenic plants of Torenia fournieri. Acta Physiol Plant 38:8. https://doi.org/10.1007/s11738-015-2028-z

Li J-W, Hosokawa M, Nabeshima T, Motoki K, Yamada H, Wang Q-C (2019) Cryopreservation of viroid-infected chrysanthemum shoot tips. Sci Hortic 244:1-9. https://doi.org/10.1016/j.scien ta.2018.09.004

Martín C, González-Benito E (2005) Survival and genetic stability of Dendranthema grandiflora Tzvelev shoot apices after cryopreservation by vitrification and encapsulation-dehydration. Cryobiol 51:281-289. https://doi.org/10.1016/j.cryobiol.2005.08.001

Martín C, González-Benito E (2009) Cryopreservation and genetic stability of Dendranthema grandiflora Tzvelev in vitro cultures. Agric Food Sci 18:129-135. https://doi.org/10.2137/1459606097 89267560

Martín C, Cervera MT, González-Benito ME (2011) Genetic stability analysis of chrysanthemum (Chrysanthemum $\times$ morifolium Ramat) after different stages of an encapsulation-dehydration cryopreservation protocol. J Plant Physiol 168:158-166. https:// doi.org/10.1016/j.jplph.2010.06.025

Martín C, Kremer C, González I, González-Benito ME (2015) Influence of the cryopreservation technique, recovery medium and genotype on genetic stability of mint cryopreserved shoot tips. Plant Cell, Tissue Organ Cult 122:185-195. https://doi.org/10.1007/ s11240-015-0760-0

Martinez-Montero ME, Harding K (2015) Cryobionomics: evaluating the concept in plant cryopreservation. In: Barh D, Khan M, Davies E (eds) PlantOmics: the omics of plant science. Springer, New Delhi, pp 655-682

Matsumoto T (2017) Cryopreservation of plant genetic resources: conventional and new methods. Rev Agric Sci 5:13-20. https://doi. org/10.7831/ras5.13

Mikuła A, Olas M, Śliwińska E, Rybczyński JJ (2008) Cryopreservation by encapsulation of Gentiana spp. cell suspension maintains regrowth, embryogenic competence and DNA content. CryoLetters 29:409-418

Mikuła A, Jata K, Rybczyński J (2009) Cryopreservation strategies for Cyathea australis (R. BR.) Domin. CryoLetters 30(6):429-439

Miler N, Kulus D (2018) Microwave treatment can induce chrysanthemum phenotypic and genetic changes. Sci Hortic 227(3):223-233. https://doi.org/10.1016/j.scienta.2017.09.047

Miler N, Zalewska M (2014) Somaclonal variation of chrysanthemum propagated in vitro from different explant types. Acta Sci Pol Hort Cult 13(2):69-82

Mukherjee AK, Dey A, Acharya L, Palai SK, Panda PC (2013) Studies on genetic diversity in elite varieties of Chrysanthemum using RAPD and ISSR markers. Indian J Biotechnol 12:161-169

Muntean CM, Leopold N, Tripon C, Coste A, Halmagyi A (2015) Surface-enhanced Raman spectroscopy of genomic DNA from in vitro grown tomato (Lycopersicon esculentum Mill.) cultivars before and after plant cryopreservation. Spectrochim Acta A 144:107-114. https://doi.org/10.1016/j.saa.2015.02.085

Murashige T, Skoog F (1962) A revised medium for rapid growth and bio assays with tobacco tissue cultures. Physiol Plant 15:473-497. https://doi.org/10.1111/j.1399-3054.1962.tb08052.x

Palai SK, Rout GR (2011) Characterization of new variety of Chrysanthemum by using ISSR markers. Hortic Brasileira 29:613-617. https://doi.org/10.1590/S0102-05362011000400029

Peakall R, Smouse PE (2012) GenAlEx 6.5: genetic analysis in Excel. Population genetic software for teaching and research-an update. Bioinformatics 28:2537-2539

Reddy AM, Jyothi UK, Vani SV, Reddy AR (2016) Evaluation of chrysanthemum (Dendranthema grandiflora Tzvelev) cultivars for flower and post-harvest quality in Alfisols of Coastal Andhra Pradesh. Ann Hortic 9(1):4-8. https://doi.org/10.5958/09764623.2016.00002.5

Rewers M, Drouin J, Kisiala A, Śliwińska E, Cholewa E (2012) In vitro regenerated wetland sedge Eriophorum vaginatum L. is genetically stable. Acta Physiol Plant 34(2):2197-2206

Rogozin IB, Pavlov YI (2003) Theoretical analysis of mutation hotspots and their DNA sequence context specificity. Mutat Res. 544(1):65-85

Sánchez-Jiménez I, Hidalgo O, Canela MA, Yakovlev SS, Solic ME, Valles J, Garnatje T (2012) Genome size and chromosome number in Echinops (Asteraceae, Cardueae) in the Aegean and Balkan regions: technical aspects of nuclear DNA amount assessment and genome evolution in a phylogenetic frame. Plant Syst Evol 298:1085-1099. https://doi.org/10.1007/s00606-012-0618-4

Schäfer-Menuhr A, Schumacher HZ, Mix-Wagner G (1997) Long-term storage of old potato varieties by cryopreservation of shoot-tips in liquid nitrogen. Plant Genet Resour Newslett 111:19-24

Shibata M, Kishimoto S, Hirai M, Aida R, Ikeda I (1998) Analysis of the periclinal chimeric structure of chrysanthemum sports by random amplified polymorphic DNA. Acta Hortic 454:347-353

Śliwińska E, Zielińska E, Jędrzejczyk I (2005) Are seeds suitable for flow cytometric estimation of plant genome? Cytometry A 64:72-79. https://doi.org/10.1002/cyto.a.20122

Tavazza R, Lucioli A, Benelli C, Giorgi D, D'aloisio E, Papacchioli V (2013) Cryopreservation in artichoke: towards a phytosanitary qualified germplasm collection. Ann Appl Biol 163:231-241. https://doi.org/10.1111/aab.12049

Teixeira da Silva JA (2014) Novel factors affecting shoot culture of chrysanthemum (Dendranthema $\times$ grandfora). Bot Lithuanica 20(1):27-40. https://doi.org/10.2478/botlit-2014-0004

Van Assche F, Clijsters H (1990) Effects of metals on enzyme activity in plants. Plant, Cell Environ 13:195-206. https://doi. org/10.1111/j.1365-3040.1990.tb01304.x

Wang R-R, Gao X-X, Chen L, Huo L-Q, Li M-F, Wang Q-C (2014) Shoot recovery and genetic integrity of Chrysanthemum morifolium shoot tips following cryopreservation by droplet-vitrification. Sci Hortic 176:330-339. https://doi.org/10.1016/j.scien ta.2014.07.031

Wettstein D (1957) Chlorophyll-letale und der submikroskopische Formwechsel der Plastiden. Exp Cell Res 12:427-487. https:// doi.org/10.1016/0014-4827(57)90165-9

Zalewska M, Kulus D (2013) Cryopreservation of in vitro-grown shoot tips of chrysanthemum by encapsulation-dehydration. Folia Hortic 25(2):133-140. https://doi.org/10.2478/fhort-2013-0015

Zalewska M, Kulus D (2014) Improvement of Chrysanthemum $\times$ grandiflorum/Ramat./Kitam. encapsulation-dehydration cryopreservation protocol. Acta Sci Pol Hort Cult 13(2):97-108 
Zalewska M, Lema-Rumińska J, Miler N (2007) In vitro propagation using adventitious buds technique as a source of new variability in chrysanthemum. Sci Hortic 113:70-73. https://doi.org/10.1016/j. scienta.2007.01.019

Zalewska M, Miler N, Tymoszuk A, Drzewiecka B, Winiecki J (2010) Results of mutation breeding activity on Chrysanthemum $\times$ grandiflorum/Ramat./Kitam. in Poland. Electr J Pol Agric Univ 13(4):27

Zarghami R, Pirseyedi M, Hasrak S, Pakdaman Sardrood B (2008) Evaluation of genetic stability in cryopreserved Solanum tuberosum. Afr J Biotechnol 7(16):2798-2802. https://doi.org/10.1079/ IVP2002325
Zevallos B, Cejas I, Rodríguez RC, Yabor L, Aragón C, González J, Engelmann F, Martinez ME, Lorenzo JC (2013) Biochemical characterization of Ecuadorian wild Solanum lycopersicum Mill. Plants produced from non-cryopreserved and cryopreserved seeds. CryoLetters 37(4):413-421

Publisher's Note Springer Nature remains neutral with regard to jurisdictional claims in published maps and institutional affiliations. 